- The digestive disorders (diarrhoea) following weaning can be largely limited through the control of the climatic conditions, the utilization of slatted floor and especially a discontinuous batch management allowing the cleaning, disinfection and non-utilization of the rooms between each passage of animals.

\title{
Influence of the variations in the main micro-climatic factors of the fattening pig house
}

\author{
C. TEXIER, B. DE LA FARGE, R. GRANIER \\ I.T.P., Service Bâtiment Environnement, \\ I49, whe de Bercy, 75595 Paris Cedex I2 \\ I.T.P., Service Bâtiment et Environnement, \\ 34, bd de la Gare, 31079 Toulouse Cedex \\ I.T.P., Station Expérimentale, Les Cabrièves, \\ I2200 Villefranche-de-Rouergue (France)
}

The experimental building used was a fattening pig house of the Danish type divided into 4 identical rooms with a capacity of 32-40 pigs each. Every room was fitted with a dynamic ventilation system (pressure above atmospheric) with rates ranging between 50 and $740 \mathrm{~m}^{3} / \mathrm{h} /$ pig and a heating system by radiation whose capacity ranged from roo to 260 millithermies /hour/ pig.

By means of an automatic regulator (I.T.P.(*) patent) it was possible at any moment to obtain different ambient conditions from one room to another. animals.

The climatic data were recorded continuously until the slaughtering of the first group of

Six trials were made from 1976 to 1978 from which the following conclusions can be drawn:

- optimum ambient conditions are obtained at high temperatures (at least 20 p. Ioo at the resultant dry temperature),

- association of a low ventilation rate (30 $\mathrm{m}^{3} /$ hour $/ \mathrm{pig}$ ) and a high air velocity $(2.5 \mathrm{~m} / \mathrm{s}$ ) leads to the best growth performance,

- the feeding level should be taken into account when choosing the ambient conditions as ad libitum fed pigs are less susceptible to climatic variations than restricted animals.

\section{Deodorization of pig manure in the piggery}

\author{
B. LEFÈ ÉE, Michèle HEDUIT \\ C.T.G.R.E.F., Division Qualité des Eaux, Pêche et Pisciculture, \\ I4, avenue de St-Mandé, 750I2 Pavis \\ G.I.D.A.|I.T.P., I 49, rue de Bercy, 75595 Paris Cedex I2
}

The aim of this study was to test the efficiency of a treatment of manure deodorization by two air-injectors blowing directly in the dunging gutter of the piggery.

Two fattening periods were observed. In the first one the ventilation times varied from I 2.5 p. IOO $\left(5.2 \mathrm{~kg}\right.$. $\mathrm{O}_{2} /$ day $)$ to 50 p. 100 working $(20.9 \mathrm{~kg} \mathrm{O} /$ day). In the second batch, from 50 p. 100 to $100 \mathrm{p}$. I00.

(*) I.T.P. : Institut Technique du Porc. 